\title{
Zika virus infection spread through saliva
}

\section{Viroj WIWANITKIT}

Surin Rajabhat University, Bangkok, Thailand.

\section{Dear Editor,}

Zika virus infection is an important problem in the present day. It is an acute hemorrhagic disease that is highly similar to dengue but it can induce neonatal problem. ${ }^{1,2}$ Based on the publication by Siqueira et al., ${ }^{3}$ the important question is whether the Zika virus infection can spread through saliva or not. Inddeed, the Zika virus can be seen in several body fluids including to urine but there is limited evidence on its appearance on saliva. The spreading or transmission via saliva can occur only if the virus can be secreted and exist in saliva and the virus can enter to the other one via mucous membrane or wound. Based on its similar viral infection, dengue, there has never been report on existence of dengue virus in saliva and transmission via saliva. ${ }^{4}$ For any new virus, another important concern is on the nanostructural size of the virus that can determine whether it can pass the physiological barrier and medical protective device to cause the infection. ${ }^{5}$ Focusing on the nanoanatomy, the molecular size of the Zika virus is similar to dengue virus. It is no doubt that the virus will pass ultrafiltration process and cellular membrane during the saliva generation and secretion. Hence, it is unlikely that the Zika virus can spread through saliva.

\section{References}

Corresponding Author:

Viroj Wiwanitkit

E-mail:wviroj@yahoo.com

DOI: $10.1590 / 1807-3107 B O R-2016 . v o l 30.0076$

Submited: Mar 17, 2016

Accepted for publication: Apr 05, 2016

Last revised: May 02, 2016
1. Joob B, Wiwanitkit V. Zika virus infection and dengue: a new problem in diagnosis in a dengue-endemic area. Ann Trop Med Public Health. 2015;8:145-6. doi:10.4103/1755-6783.162402

2. Wiwanitkit $S$, Wiwanitkit V. Acute viral hemorrhage disease: a summary on new viruses. J Acute Dis. 2015;4(4):277-9. doi:10.1016/j.joad.2015.06.004

3. Siqueira WL, Moffa EB, Mussi MC, Machado MA. Zika virus infection spread through saliva - a truth or myth? Braz Oral Res. 2016;30(1):e46. doi:10.1590/1807-3107BOR-2016.vol30.0046

4. Wiwanitkit V. Unusual mode of transmission of dengue. J Infect Dev Ctries. 2009;4(1):51-4. doi:10.3855/jidc.145

5. Wiwanitkit V. N-95 face mask for prevention of bird flu virus: an appraisal of nanostructure and implication for infectious control. Lung. 2006;184(6):373-4. doi:10.1007/s00408-006-0021-4 